\title{
SUPERCOMPUTER SIMULATION OF OIL SPILLS IN THE AZOV SEA
}

\author{
A.I. Sukhinov ${ }^{1}$,A.E. Chistyakov ${ }^{1}, A . A$. Filina $^{2}$, A.V. Nikitina ${ }^{3}$, \\ V.N. Litvinov ${ }^{4}$ \\ ${ }^{1}$ Don State Technical University, Rostov-on-Don, Russian Federation \\ ${ }^{2}$ Supercomputers and Neurocomputers Research Center, Taganrog, Russian Federation \\ ${ }^{3}$ Southern Federal University, Rostov-on-Don, Russian Federation \\ ${ }^{4}$ Azov-Black Sea Engineering Institute of Don State Agrarian University, Zernograd, \\ Russian Federation \\ E-mails: sukhinov@gmail.com, cheese_05@mail.ru, j.a.s.s.y@mail.ru, \\ nikitina.vm@gmail.com, litvinovvn@rambler.ru
}

We present the research on microbiological destruction of oil pollution in shallow water. In order to conduct the research, we use a multiprocessor computer system with distributed memory. The research takes into account the oil fractional composition as well as hydrodynamic and chemical-biological features of water. In order to simulate the dynamics of hydrocarbon microbiological degradation in the Azov Sea, we propose the complex of interrelated precision models. For model discretization, we use the space splitting schemes taking into account the partial filling cells of computational domain. Therefore, the computational accuracy significantly increases, while the computational time decreases. On supercomputer, we implement an experimental software for predictive modelling the ecological situation under oil and other pollution conditioned by natural and industrial challenges in shallow water.

Keywords: oil pollution; biodegradation of petroleum hydrocarbons; shallow water; mathematical model; algorithm; supercomputer.

\section{Introduction}

Recently, increase in oil production led to increase in emergencies associated with oil spill during transportation both by vessels and through the oil pipeline in Russia. Among sources of oil pollution, we note river runoffs, wastewater from enterprises located in coastal zones, drilling mud and sludge discharges at oil and gas well drilling, dumping of polluted bottom sediments of port zones, atmospheric precipitation and aeolian depositions. The oil has a toxic effect on phytoplankton at concentrations of $10^{-8}-10^{-3} \mathrm{mg} / \mathrm{l}$ (cell division slows down or stops, the main production decreases). If the oil concentration is $0,05-0,5$ $\mathrm{mg} / \mathrm{l}$, then primary production of marine phytoplankton is reduced to $50 \%$.

Among the most well-known programs for predicting the oil spill spread in water, we note the "Green Sea Ranger" model of the "Korea Research Institute of Ships and Ocean Engineering"; application programs (SHIO, OSSM, CATS, GNOME Analyst) of the US Agency "National Oceanic and Atmospheric Administration" (NOAA); the "Seatrack the Web" interactive numerical model of the Swedish Institute for Meteorology and Hydrology (SMHI). However, many models represent oil slick distribution, which is in agreement with real situation only at the initial stages of spill.

Analysis of numerical solution to the material transport model problem shows that time costs are reduced, then the grid dimension of explicit scheme increases. Modification of the explicit scheme using the parameter-regularizater can simplify the restrictions on the 
permissible value of time step [3]. In addition, explicit regularized schemes show the time advantages (10 - 15 times and more) in contrast with the previously used conventional implicit and no-regularized explicit schemes [4]. In the case of filling control domains, the variation of the finite volume method was proposed in $[5,6]$. Algorithm of calculation taking into account the partial "fillness" of cells without flows is associated with a stepwise representation of a boundary on a rectangular grid. The proposed method was applied to solve three-dimensional hydrodynamic problems [7-9].

\section{Problem Statement}

The complex of interrelated mathematical models of hydrodynamics and biological kinetics was used for mathematical modelling of oil destruction processes. Flow fields, used for calculation of the oil products transport, was calculated on the basis of this model.

\subsection{Mathematical Model of Hydrophysics}

The initial equations of hydrodynamics of shallow waters are as follows $[10,11]$ :

- the motion equation (the Navier-Stokes motion equation)

$$
\begin{gathered}
u_{t}^{\prime}+u u_{x}^{\prime}+v u_{y}^{\prime}+w u_{z}^{\prime}=-\frac{1}{\rho} p_{x}^{\prime}+\left(\mu u_{x}^{\prime}\right)_{x}^{\prime}+\left(\mu u_{y}^{\prime}\right)_{y}^{\prime}+\left(\nu u_{z}^{\prime}\right)_{z}^{\prime}+2 \Omega(v \sin \theta-w \cos \theta), \\
v_{t}^{\prime}+u v_{x}^{\prime}+v v_{y}^{\prime}+w v_{z}^{\prime}=-\frac{1}{\rho} p_{y}^{\prime}+\left(\mu v_{x}^{\prime}\right)_{x}^{\prime}+\left(\mu v_{y}^{\prime}\right)_{y}^{\prime}+\left(\nu v_{z}^{\prime}\right)_{z}^{\prime}-2 \Omega u \sin \theta, \\
w_{t}^{\prime}+u w_{x}^{\prime}+v w_{y}^{\prime}+w w_{z}^{\prime}=-\frac{1}{\rho} p_{z}^{\prime}+\left(\mu w_{x}^{\prime}\right)_{x}^{\prime}+\left(\mu w_{y}^{\prime}\right)_{y}^{\prime}+\left(\nu w_{z}^{\prime}\right)_{z}^{\prime}+2 \Omega u \cos \theta+g\left(\rho_{0} / \rho-1\right) ;
\end{gathered}
$$

- in the case of variable density, the continuity equation

$$
\rho_{t}^{\prime}+(\rho u)_{x}^{\prime}+(\rho v)_{y}^{\prime}+(\rho w)_{z}^{\prime}=0
$$

where $\mathbf{u}=(u, v, w)$ is a velocity vector; $p$ is an excess pressure above the undisturbed fluid hydrostatic pressure; $\rho$ is a density; $\Omega$ is an Earth's angular velocity rotation; $\theta$ is an angle between the angular velocity vector and the vertical vector; $\mu, \nu$ are horizontal and vertical components of the turbulent exchange coefficient, respectively.

Consider system of equations (1), (2) with the following boundary conditions:

- at the input (the mouth of Don and Kuban rivers),

$$
\mathbf{u}=\mathbf{u}_{\mathbf{0}}, p_{n}^{\prime}=0 \text {, }
$$

- on the lateral boundary (beach and bottom),

$$
\rho_{v} \mu\left(\boldsymbol{u}_{\tau}\right)_{n}^{\prime}=-\boldsymbol{\tau}, \mathbf{u}_{\mathbf{n}}=0, p_{n}^{\prime}=0,
$$

- on the upper boundary,

$$
\rho \mu\left(\boldsymbol{u}_{\boldsymbol{\tau}}\right)_{n}^{\prime}=-\boldsymbol{\tau}, w=-\omega-p_{t}^{\prime} / \rho g, p_{n}^{\prime}=0,
$$

- at the output (Kerch Strait),

$$
p_{n}^{\prime}=0, \mathbf{u}_{\mathbf{n}}^{\prime}=0,
$$

where $\mathbf{n}$ is the outer normal vector to the boundary of the computational domain; $\mathbf{u}_{\mathbf{n}}$, $\boldsymbol{u}_{\boldsymbol{\tau}}$ are the normal and tangential components of the water flow velocity vector; $p_{n}$ is the normal component of the pressure over hydrostatic pressure; $\omega$ is the liquid evaporation intensity; $\boldsymbol{\tau}=\left\{\tau_{x}, \tau_{y}, \tau_{z}\right\}$ is the tangential stress vector (Van-Dorn law); $\rho_{v}$ is the suspension density.

For the free surface, the tangential stress vector is defined as $\boldsymbol{\tau}=\rho_{a} C d_{s}|\mathbf{w}| \mathbf{w}, C d_{s}=$ 0,0026 , where $\mathbf{w}$ is the vector of the wind speed relative to water; $\rho_{a}$ is the density of the 
atmosphere; $C d_{s}$ is the dimensionless surface drag coefficient, which depends on the wind speed and is considered to be in the range 0,0016-0,0032.

In these terms, we can rewrite the tangential stress vector for the bottom as $\boldsymbol{\tau}=$ $\rho C d_{b}|\mathbf{u}| \mathbf{u}, C d_{b}=g k^{2} / h^{1 / 3}$, where $k=0,04, k$ is the group coefficient of roughness in Manning's formula, $k \in[0,025,0,2] ; h=H+\eta, h$ is the total depth of the water area, $[\mathrm{m}] ; H$ is the depth to undisturbed surface, $[\mathrm{m}] ; \eta$ is the height of the free surface relative to the geoid (Sea level), [m].

On the basis of the measured velocity fluctuations, the discussed below approximation is required to develop the coefficient of vertical turbulent exchange, which is heterogeneous in depth [6]:

$$
\nu=C_{s}^{2} \Delta^{2} \frac{1}{2} \sqrt{\left(\frac{\partial U}{\partial z}\right)^{2}+\left(\frac{\partial V}{\partial z}\right)^{2}},
$$

where $U, V$ are the time-averaged pulsations of the horizontal velocity components; $\Delta$ is the grid scale; $C_{s}$ is the dimensionless empirical constant, whose value is generally determined by calculation of the decay of homogeneous isotropic turbulence. The grid method is used to solve problem (1) - (4) [12]. The approximation of equations by the time variable is performed by splitting schemes into physical processes [13] using the pressure correction method.

\subsection{Mathematical Model of Oil Spill Transport}

The following system of equations is used to describe the process of oil products transport, which is subject to the evaporation of light, neutral and no-evaporating pseudofractions of oil spot, dissolution of oil slick and biodegradation [14-17]:

$$
\begin{gathered}
\left(c_{i}\right)_{t}^{\prime}+u\left(c_{i}\right)_{x}^{\prime}+v\left(c_{i}\right)_{y}^{\prime}=\left(\mu^{*}\left(c_{i}\right)_{x}^{\prime}\right)_{x}^{\prime}+\left(\mu^{*}\left(c_{i}\right)_{y}^{\prime}\right)_{y}^{\prime}-\alpha_{i}(T)-\beta_{i}\left(c_{i}\right) M, \\
M_{t}^{\prime}+\left(u+u_{M}\right) M_{x}^{\prime}+\left(v+v_{M}\right) M_{y}^{\prime}=\left(\mu M_{x}^{\prime}\right)_{x}^{\prime}+\left(\mu M_{y}^{\prime}\right)_{y}^{\prime}+\gamma_{M}\left(c_{i}\right) M-\lambda M, \\
\left(\varphi_{i}\right)_{t}^{\prime}+u\left(\varphi_{i}\right)_{x}^{\prime}+v\left(\varphi_{i}\right)_{y}^{\prime}+w\left(\varphi_{i}\right)_{z}^{\prime}=\left(\mu^{*}\left(\varphi_{i}\right)_{x}^{\prime}\right)_{x}^{\prime}+\left(\mu^{*}\left(\varphi_{i}\right)_{y}^{\prime}\right)_{y}^{\prime}+\left(\mu^{*}\left(\varphi_{i}\right)_{z}^{\prime}\right)_{z}^{\prime}, \\
\left.\left(c_{i}\right)_{n}^{\prime}\right|_{(x, y) \in \gamma}=0,\left.M_{n}^{\prime}\right|_{(x, y) \in \gamma}=0,\left.\quad\left(\varphi_{i}\right)_{n}^{\prime}\right|_{(x, y, z) \in \Gamma \backslash(z=0)}=0,\left.\quad\left(\varphi_{i}\right)_{z}^{\prime}\right|_{(z=0)}=0,
\end{gathered}
$$

where $c_{i}$ is the concentration of the $i$-th oil fractions, $i=\overline{1, k} ; \rho_{\omega}, \rho$ are the water and oil density, respectively; $\mu^{*}=\mu+\left(\rho-\rho_{\omega}\right) g h^{3} / \mu$ is the function describing the pollutant decomposition process; $\mu$ is the diffusion coefficient; $g$ is the acceleration; $h=\sum_{1}^{l} c_{i}$ is the width of oil slick; $\alpha_{i}, \beta_{i}$ are the coefficients taking into account the decrease in light oil fraction concentration due to the evaporation, dissolution, and bacterial decomposition; $M$ is the concentration of microorganisms; $\mathbf{u}_{M}=\left(u_{M}, v_{M}\right), u_{M}, v_{M}$ are the components of microorganism velocity relative to water; $\gamma_{M}=\gamma_{M}\left(c_{i}, T\right)$ is the velocity of microorganism growth; $\lambda$ is the rate of cell death; $\varphi_{i}$ is the concentration of the $i$-th oil fraction in dissolved state, $i=\overline{k+1, l}$.

Changes of the oil solubility are described by the equation

$$
S_{i}=S_{i 0} e^{-0,1 t}
$$

where $S_{i 0}$ is the initial oil solubility; $t$ is the time, [day]. The coefficient of horizontal turbulent diffusion depends on hydrodynamic and climatic conditions under which the process takes place. The coefficient of horizontal turbulent diffusion is subject to the "four thirds" law of Richardson under difficult hydrodynamic and climatic conditions of the Azov-Black Sea area $[1,14]$ : 


$$
\mu \approx \varepsilon^{1 / 3} L^{4 / 3}
$$

where $L$ is the characteristic size of diffusing spots; $\varepsilon$ is the rate of turbulent energy dissipation, which has the order $10^{-1}-1 \mathrm{~cm}^{2} / \mathrm{s}^{3}$ at the surface and is reduced to the order $10^{-4}-10^{-3} \mathrm{~cm}^{2} / \mathrm{s}^{3}$ at the average along with depth. For the one-shot volley oil spill, the following boundary and initial conditions are determined to solve the above systems of equations:

$$
\left.c_{i}\right|_{t=0,(x, y) \in A}=c_{i 0},\left.\quad c_{i}\right|_{t=0,(x, y) \notin A}=0,
$$

where $A$ is the area covered by the spot; $c_{i 0}$ is the oil concentration in the considered area.

\subsection{Modelling the Microbiological Destruction Processes of Oil and Oil Products}

In order to research the bioremediation processes of oil slick including the evaporation, dissolution, biological oxidation by microorganisms, we endow system (5) with the functional dependencies (observation models) $\gamma\left(c_{i}\right)=$ $\mu_{m} c_{i} /\left(c_{i}+K_{S}\right)$, where $\mu_{m}(T, C, I)$ is the maximum velocity of microorganism growth; $T$ is the ambient temperature over the spill surface; $C$ is the water salinity; $I$ is the water illumination; $K_{S}$ is the saturation coefficient; $\alpha_{i}(T)=\left(K_{E} P_{i} /(R T)+K_{D} S_{i}\right) A X_{i} M_{i}^{m}, \quad K_{E}=2,5 \cdot 10^{-3} U^{0,78}$ is the mass transport coefficient for hydrocarbon, $[\mathrm{m} / \mathrm{s}] ; \quad U$ is the wind velocity relatively to water, $[\mathrm{m} / \mathrm{s}] ; \quad X_{i}$ is the mole fraction of the $i$-th component equaled to $v_{i} / \sum v_{i} ; \quad v_{i}$ is the amount of the $i$-th component substance, [mol]; $P_{i}$ is the vapor pressure of the $i$-th component, $[\mathrm{Pa}] ; R$ is the universal gas constant, $R=8,314 \mathrm{~J} / \mathrm{mol} ; A$ is the area of oil spill, $\left[m^{2}\right] ; M_{i}^{m}$ is the molar mass of the $i$-th component, $[\mathrm{kg} / \mathrm{mol}] ; K_{D}=k K_{D 0}$ is the coefficient of mass transport of dissolution; $K_{D 0}$ is the initial value of the mass transport coefficient of dissolution; $k$ is the coefficient depending on the water situation; $S_{i}$ is the dissolubility of the $i$-th component in water, $\left[\mathrm{kg} / \mathrm{m}^{3}\right] ; \varphi_{i 0}=K_{D} S_{i} X_{i} M_{i}^{m} ; \beta_{i}\left(c_{i}\right)=\gamma\left(c_{i}\right) / q, q$ is the proportion coefficient between the amount of microorganisms and the absorbed substrate.

We endow system (5) with the equation [18]

$\left(\mathbf{u}_{M}\right)_{t}^{\prime}+\left(u+u_{M}\right)\left(\mathbf{u}_{M}\right)_{x}^{\prime}+\left(v+v_{M}\right)\left(\mathbf{u}_{M}\right)_{y}^{\prime}=\left(\mu\left(\mathbf{u}_{M}\right)_{x}^{\prime}\right)_{x}^{\prime}+\left(\mu\left(\mathbf{u}_{M}\right)_{y}^{\prime}\right)_{y}^{\prime}-\alpha_{u} \mathbf{u}_{M}+k_{i} \operatorname{grad} c_{i}$, where $M$ is the microorganism concentration (bacteria); $\alpha_{u}$ is the coefficient of microorganism inertial motion; $k_{i}$ is the taxis ratio.

In order to research the microbiological oil destruction process, we simulate the introduction of biosorbent containing oil-oxidizing bacteria and the concentrated culture of the Chlorella vulgaris Beijer green microalgae. The coefficient $\lambda$ takes into account not only the mortality of phytoplankton, but also the consumption of the phytoplankton by fish. We endow system (5) with the following two equations:

$$
\begin{gathered}
S_{t}^{\prime}+u S_{x}^{\prime}+v S_{y}^{\prime}+w S_{z}^{\prime}=\left(\mu S_{x}^{\prime}\right)_{x}^{\prime}+\left(\mu S_{y}^{\prime}\right)_{y}^{\prime}+\left(\mu S_{z}^{\prime}\right)_{z}^{\prime}-\left(\alpha_{0}+\gamma B\right) \psi M+D\left(S_{p}-S\right)+f, \\
B_{t}^{\prime}+u B_{x}^{\prime}+v B_{y}^{\prime}+w B_{z}^{\prime}=\left(\mu B_{x}^{\prime}\right)_{x}^{\prime}+\left(\mu B_{y}^{\prime}\right)_{y}^{\prime}+\left(\mu B_{z}^{\prime}\right)_{z}^{\prime}+k_{B} M-\varepsilon B,
\end{gathered}
$$

where $S, B$ are the concentrations of nutrient and metabolite of the Chlorella vulgaris Beijer green algae, respectively; $\alpha=\left(\alpha_{0}+\gamma B\right)$ is the growth dependence (the phytoplancton) due to the coefficient $B ; \alpha_{0}$ is the growth rate of $M$ in the absence of the coefficient $B ; \gamma$ is the impact parameter; $\delta=\delta(C)$ is the loss coefficient of phytoplankton 
due to the extinction (specific mortality), taking into account the influence of salinity $C$; $D$ is the specific pollutant rate; $f(x, y, z, t)$ is the source function of pollutants; $S_{p}$ is the maximum possible concentration of pollutants; $k_{B}$ is the excretion rate; $\varepsilon$ is the metabolite decomposition of the coefficient $B ; \psi(I, T, S, C)$ is the coefficient taking into account the effect of light, temperature, $S$ and $C$ on $M$.

\section{Method to Solve the Model Problems}

In order to implement the oil product transport model, consider the two-dimensional convection-diffusion problem in the form

$$
c_{t}^{\prime}+u c_{x}^{\prime}+v c_{y}^{\prime}=\left(\mu c_{x}^{\prime}\right)_{x}^{\prime}+\left(\mu c_{y}^{\prime}\right)_{y}^{\prime}+f
$$

with the boundary conditions

$$
c_{n}^{\prime}(x, y, t)=\alpha_{n} c+\beta_{n}
$$

where $u, v$ are the water velocity components; $\mu$ is the turbulent exchange coefficient; $f$ is the function, describing the intensity and distribution of sources; $\alpha_{n}, \beta_{n}$ are the given coefficients.

Introduce the uniform rectangular grid

$$
\begin{gathered}
\omega_{h}=\left\{t^{n}=n \tau, x_{i}=i h_{x}, y_{j}=j h_{y} ; n=\overline{0, N_{t}}, i=\overline{0, N_{x}}, j=\overline{0, N_{y}},\right. \\
\left.N_{t} \tau=T, N_{x} h_{x}=l_{x}, N_{y} h_{y}=l_{y}\right\},
\end{gathered}
$$

where $\tau$ is the time step; $h_{x}, h_{y}$ are the spatial steps; $N_{t}$ is the upper time boundary; $N_{x}$, $N_{y}$ are the spatial boundaries; $l_{x}, l_{y}$ are the maximum dimensions of the computational domain.

For model discretization of the oil products transport problem, we use the space splitting scheme taking into account the partial filling of cells [12]. The discrete analogue of diffusion-convection equation (7) has the form

$$
\begin{gathered}
\frac{q_{i, j}^{n+1 / 2}-q_{i, j}^{n}}{\tau}+\psi_{x L} \frac{q_{i-1, j}^{n-1 / 2}-q_{i-1, j}^{n-1}}{2 \tau}+\psi_{x R} \frac{q_{i+1, j}^{n-1 / 2}-q_{i+1, j}^{n-1}}{2 \tau}+u \frac{q_{i+1, j}^{n}-q_{i-1, j}^{n}}{4 h_{x}}+ \\
+\psi_{x L} u \frac{q_{i, j}^{n}-q_{i-1, j}^{n}}{h_{x}}+\psi_{x R} u \frac{q_{i+1, j}^{n}-q_{i, j}^{n}}{h_{x}}=3 / 2 \mu \frac{q_{i+1, j}^{n}-2 q_{i, j}^{n}+q_{i-1, j}^{n}}{h_{x}^{2}}+1 / 2\left(g\left(q_{i, j}^{n}\right)+\eta_{i, j}^{n}\right) \\
\frac{q_{i, j}^{n+1}-q_{i, j}^{n+1 / 2}}{\tau}+\psi_{y L} \frac{q_{i, j-1}^{n}-q_{i, j-1}^{n-1 / 2}}{2 \tau}+\psi_{y R} \frac{q_{i, j+1}^{n}-q_{i, j+1}^{n-1 / 2}}{2 \tau}+v \frac{q_{i, j+1}^{n+1 / 2}-q_{i, j-1}^{n+1 / 2}}{4 h_{y}}+ \\
+\psi_{y L} v \frac{q_{i, j}^{n+1 / 2}-q_{i, j-1}^{n+1 / 2}}{h_{y}}+\psi_{y R} v \frac{q_{i, j+1}^{n+1 / 2}-q_{i, j}^{n+1 / 2}}{h_{y}}= \\
=3 / 2 \mu \frac{q_{i, j+1}^{n+1 / 2}-2 q_{i, j}^{n+1 / 2}+q_{i, j-1}^{n+1 / 2}}{h_{y}^{2}}+1 / 2\left(g\left(q_{i, j}^{n}\right)+\eta_{i, j}^{n}\right)
\end{gathered}
$$

where $\psi_{x L}=1, \psi_{x R}=0$ for $u>0$, and $\psi_{x L}=0, \psi_{x R}=1$ for $u<0 ; \psi_{y L}=1, \psi_{y R}=0$ for $v>0$, and $\psi_{y L}=0, \psi_{y R}=1$ for $v<0$ [11].

The research of scheme (9) shows that the scheme is stable at the Courant numbers in the interval $[0 ; 0,75]$ and the large Peclet numbers $(P e>20)$. In the limiting case (the diffusion coefficient is equal to zero) at large Peclet numbers, the maximum value of the numerical solution error of problem (7) obtained by proposed difference scheme (9) is equaled to 0,125 . The numerical solution error obtained by scheme (9) is less than the solution error of problem (7) obtained by the discretization of standard difference schemes. 


\section{Parallel Implementation as a Software Complex}

Decomposition methods of grid domains are performed for computationally laborious convection-diffusion problems in parallel implementation taking into account parameters of multiprocessor systems' architecture. The maximum performance of multiprocessor computer system (MCS) is equaled to 18.8 TFlops. As computational nodes, we use 512 single-type of 16-core Blade-servers HP ProLiant BL685, each of which has the four quadcore AMD Opteron processor 8356 of $2.3 \mathrm{GHz}$ and memory, which is equaled to $32 \mathrm{~GB}$. Table 1 gives the time costs required for one time layer on various grids, as well as the acceleration and efficiency values for different numbers of MCS cores.

Table 1

Acceleration and efficiency of the number of processors $(p)$ for one time layer

\begin{tabular}{|c|c|c|c|c|c|}
\hline$p$ & Computational domain & $100 \times 100$ & $500 \times 500$ & $1000 \times 1000$ & $5000 \times 5000$ \\
\hline \multirow[t]{3}{*}{1} & Time, s & 0,000271 & 0,00846 & 0,03608 & 1,633 \\
\hline & Acceleration & 1 & 1 & 1 & 1 \\
\hline & Efficiency & 1 & 1 & 1 & 1 \\
\hline \multirow[t]{3}{*}{4} & Time, s & 0,000052 & 0,00341 & 0,00978 & 0,533 \\
\hline & Acceleration & 5,212 & 2,481 & 3,689 & 3,064 \\
\hline & Efficiency & 1,303 & 0,62 & 0,922 & 0,766 \\
\hline \multirow[t]{3}{*}{16} & Time, s & 0,000025 & 0,00054 & 0,00628 & 0,142 \\
\hline & Acceleration & 10,84 & 15,667 & 5,745 & 11,5 \\
\hline & Efficiency & 0,677 & 0,979 & 0,359 & 0,719 \\
\hline \multirow[t]{3}{*}{64} & Time, s & 0,000125 & 0,00016 & 0,00110 & 0,044 \\
\hline & Acceleration & 2,168 & 52,875 & 32,8 & 37,114 \\
\hline & Efficiency & 0,034 & 0,826 & 0,513 & 0,58 \\
\hline \multirow[t]{3}{*}{128} & Time, s & - & 0,00040 & 0,00048 & 0,017 \\
\hline & Acceleration & - & 21,15 & 75,167 & 96,059 \\
\hline & Efficiency & - & 0,165 & 0,587 & 0,75 \\
\hline \multirow[t]{3}{*}{512} & Time, s & - & - & 0,00129 & 0,0072 \\
\hline & Acceleration & - & - & 27,883 & 228,36 \\
\hline & Efficiency & - & - & 0,054 & 0,446 \\
\hline
\end{tabular}

For numerical implementation of proposed interrelated mathematical hydrophysics models, we develop parallel algorithms adapted for hybrid computer systems using the NVIDIA CUDA architecture (Fig. 1).

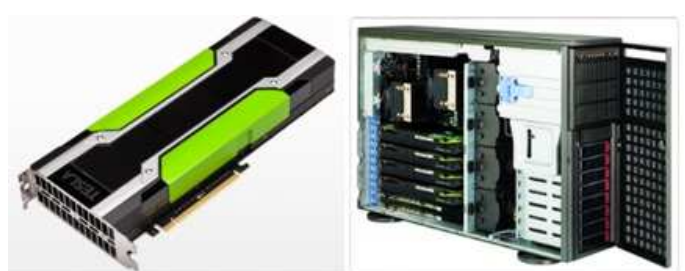

Fig. 1. The NVIDIA Tesla K80

The NVIDIA Tesla K80 computing accelerator has the high computing performance and supports all modern both the closed (CUDA) and open technologies (OpenCL, DirectCompute). The NVIDIA Tesla K80 specifications are the following: the GPU frequency of $560 \mathrm{MHz}$, the GDDR5 video memory of $24 \mathrm{~GB}$, the video memory frequency of $5000 \mathrm{MHz}$, the video memory bus digit capacity of 768 bits. The NVIDIA CUDA platform characteristics are the following: Windows 10 (x64) operating system, CUDA Toolkit 
v10.0.130, Intel Core i5-6600 3.3 GHz processor, DDR4 of RAM $32 \mathrm{~GB}$, the NVIDIA GeForce GTX 750 Ti video card of 2GB, 640 CUDA cores.

The GPU with the CUDA technology is required to address the effective resource distribution at solving the system of linear algebraic equations (SLAE). In order to implement the corresponding algorithm, we obtain the dependence of the SLAE solution time on the matrix dimension and the number of nonzero diagonals (see Fig. 2). As a result, in particular, we can choose the grid size and to determine the SLAE solution time based on the number of nonzero matrix diagonals.

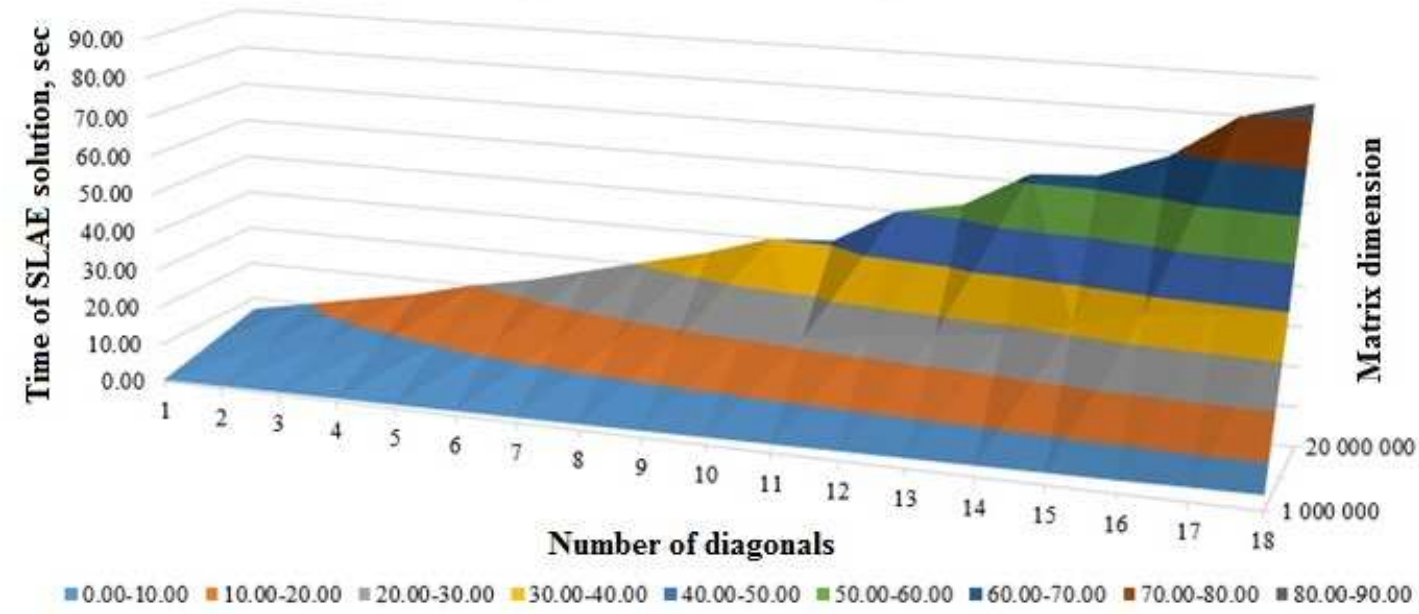

Fig. 2. Dependence of the SLAE solution time on matrix dimension and the number of nonzero diagonals

We implement the experimental software complex (SC) for mathematical modelling of shallow water ecosystems on the example of the Azov-Black Sea basin. Due to the $\mathrm{SC}$, we can construct the operational forecast of movement of turbulence flow of water environment, i.e. the velocity field on grids with high resolution. The $\mathrm{SC}$ is used to calculate the three-dimensional velocity vector of the Azov Sea. The SC takes into account such physical parameters as the Coriolis force, the turbulent exchange, the complex geometry of bottom surface and coastline, evaporation, river flows, wind-surges, wind currents and friction bottom, and allows to calculate velocity field without pressure, hydrostatic pressure (used as an initial approximation for the hydrodynamic pressure), hydrodynamic pressure, and three-dimensional velocity field of water flow.

The output parameters are steps by spatial coordinates, error of grid equations' calculation, grid dimension, time interval, evaporation intensity, initial distribution of velocity vector components of water environment and pressure.

We develop and integrate to this $\mathrm{SC}$ the new modules in order to calculate the oil products transport in view of the evaporation of light, neutral and no-evaporating pseudofractions of oil slick, dissolution and biodegradation.

In order to calibrate and verify the developed hydrophysics models included in the SC, we use the "ESIMO" data [19] (Fig. 3), the NOAA data [20] (Fig. 4), and the "Analytical GIS" portal [21]. As input data, we use the NASA data [22], the Earth satellite sensing data of the Scientific Research Center (SRC) "Planeta" [23] (Fig. 5, 6), [25-29], the data of the Azov Fisheries Research Institute ("AzNIIRH"), the Federal State Institution (FSI) "Azovmorinformtsentr", expeditionary researches [30,31]. 


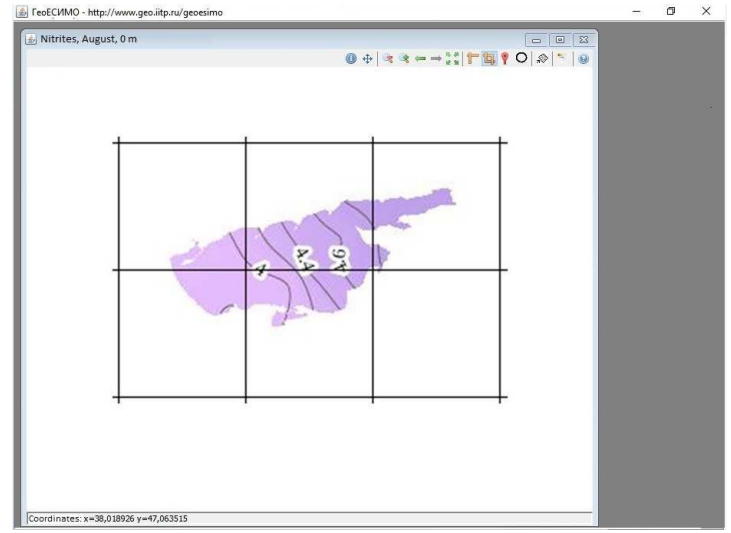

Fig. 3. "ESIMO" portal navigation panel that shows nitrites in the Azov Sea

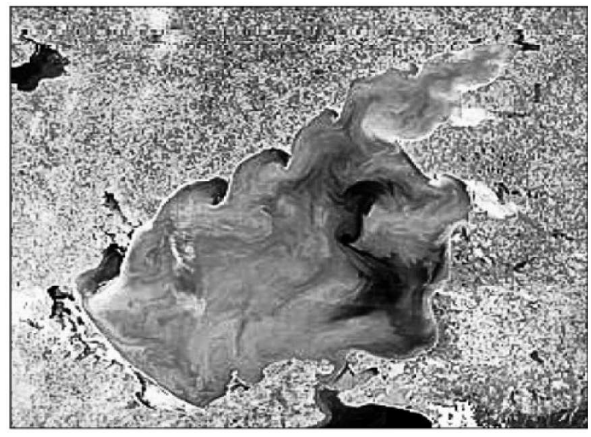

a)

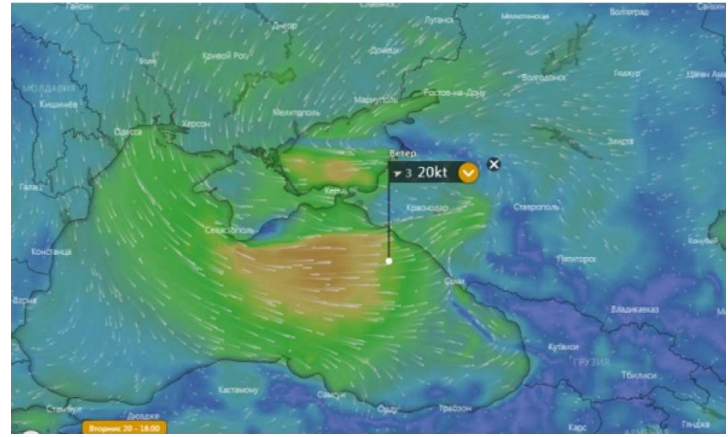

b)

Fig. 4. Earth satellite sensing data: a) the Azov Sea satellite image in ultraviolet spectrum (visible spots of phytoplankton, revealing the structure of currents);

b) the wind velocity and direction in the Azov-Black Sea basin

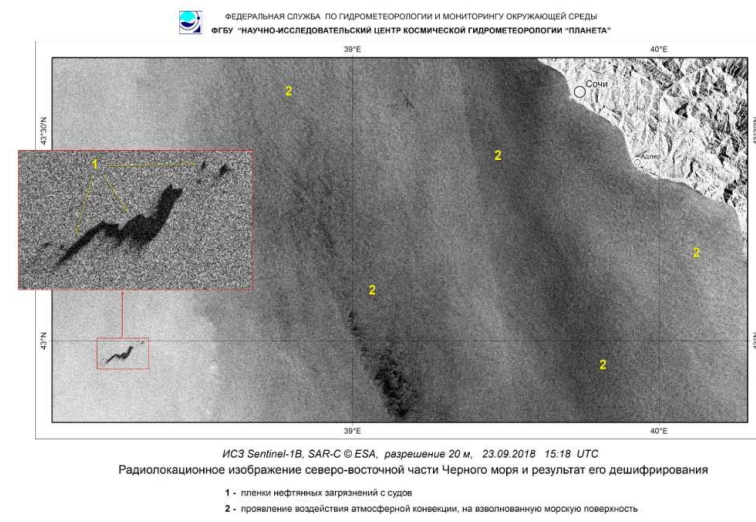

Fig. 5. SRC "Planet" data that gives description of oil pollution in the Azov-Black Sea basin

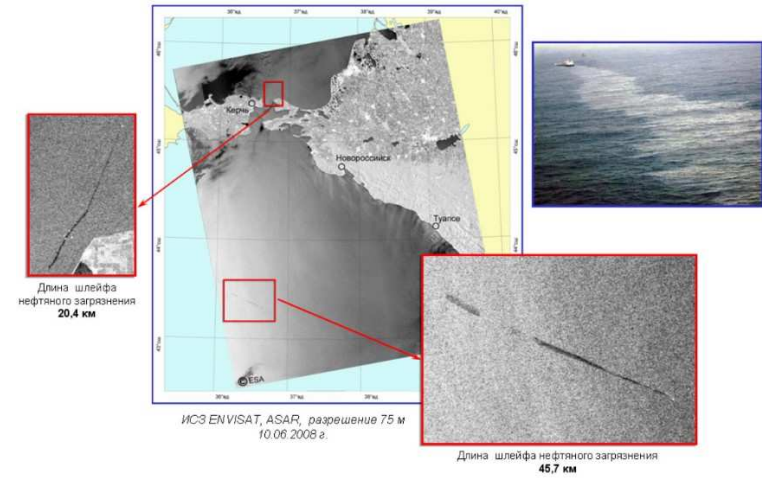

Fig. 6. IS3 Envisat radar image of oil slicks

The paper [10] gives the results of natural experiments for researching the crude oil destruction in seawater. According to the experimental results, only $3-15 \%$ of original amount of crude oil is subject to oxidation, biodegradation, photochemical reactions, while $10-40 \%$ of the substance is evaporated. According to the paper [24], the containment time should not exceed 4 hours since oil spill in water, and 6 hours since the discovery of oil spill on the ground for providing the information about spill upon receiving a message about spill. \& Computer Software (Bulletin SUSU MMCS), 2019, vol. 12, no. 3, pp. 115-129 
Fig. 7 shows numerical simulation of petroleum hydrocarbons' bioremediation process by introduction of the oil-degrading bacteria in coastal system (the Azov Sea) $(N$ is the number of iteration). The initial distribution of light oil fraction is shown in Fig. 7 a, while the distribution of light oil fraction (two oil slicks) is shown in Fig. $7 \mathrm{~b}(N=121)$. The initial distribution of heavy oil fraction is shown in Fig. $7 \mathrm{c}$, while the distribution of heavy oil fraction concentration (a single localized spill with the subsidence of oil hydrocarbons to the water bottom $)$ is shown in Fig. $7 \mathrm{~d}(N=$ 148).

In the considered case, there is no localization measures of oil spills. According to the results of natural experiments, the

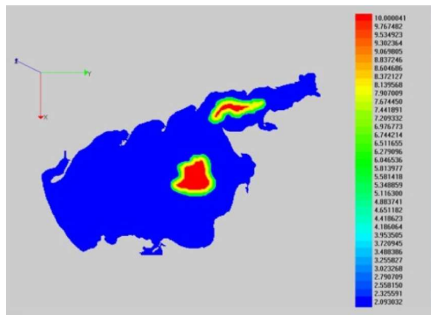

a)

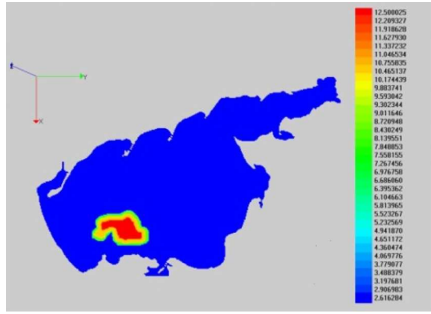

c)

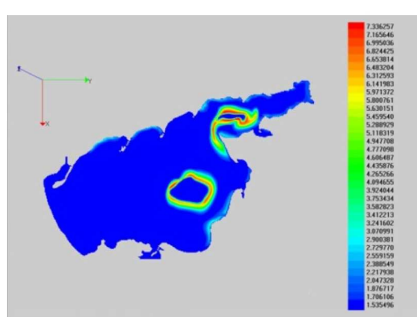

b)

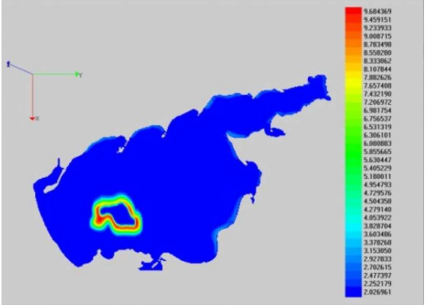

d)

Fig. 7. Results of the "Azov3d" SC simulation calculated time must be equal to $20-30$ days. The wind velocity $3-8 \mathrm{~m} / \mathrm{s}$ is an ideal for localization of the oil pollution. In this case, the slicks appear as dark spots on the bright (rough) water surface (see Fig. 8 a). The highest wind velocity was fixed in November 11, 2007 in Kerch Strait and amounted to $24 \mathrm{~m} / \mathrm{s}$ according to the Gismeteo data.

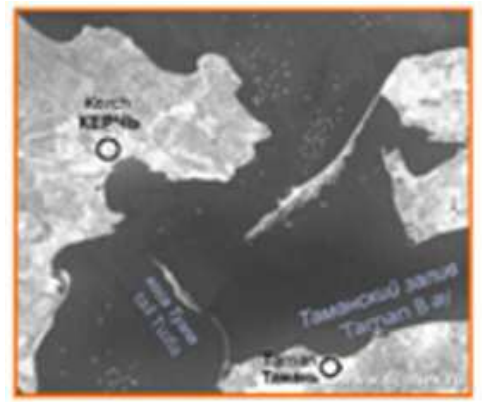

a)

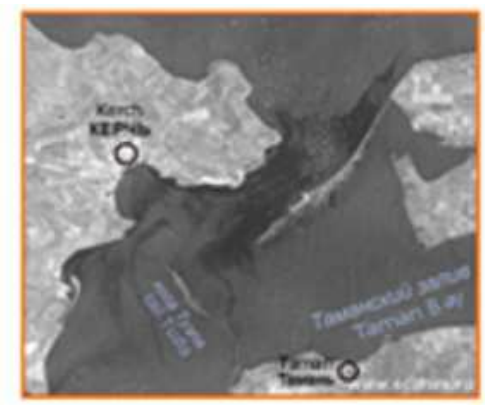

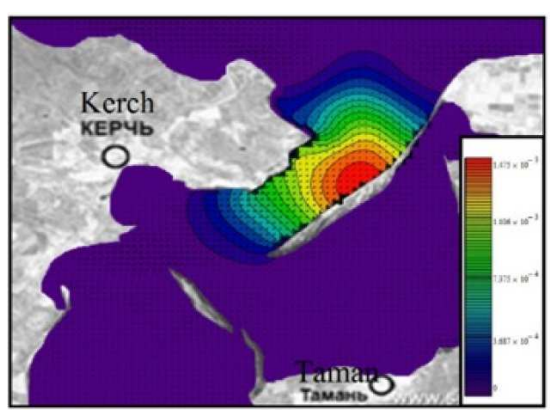

b)

Fig. 8. Oil spill simulation using the "Azov3d" SC: a) the radar image during the spill;

b) the concentration fields of light oil products

Results of numerical experiments of light oil transport simulation in the Kerch Strait on November 16, 2007 (Fig. 8 b) was obtained on the basis of the developed SC and used to test the efficiency of this complex [26]. Compare the calculation results of the light oil product concentration (see Fig. 8 b) and the radar images of catastrophic oil spill (Fig. 8 a). Their qualitative agreement is obvious. The simulation time is 4 days after spill.

Simulation time interval was 30 days (Fig. 9 b). In the case of the source oil pollution (two oil slicks), the sorbed oil is reduced to $30-40 \%$. This fact corresponds to the oil distribution process in water at the qualitative and quantitative levels. Fig. 9 shows the numerical simulation of the petroleum hydrocarbon phytoremediation process by the water algolization (the Azov Sea) with the Chlorella vulgaris Beijer green microalgae. 


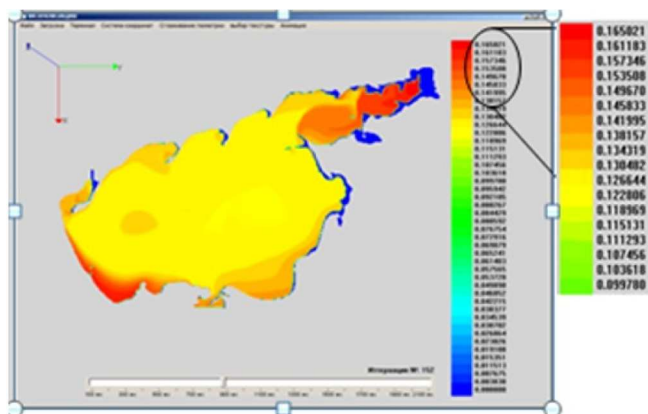

a)

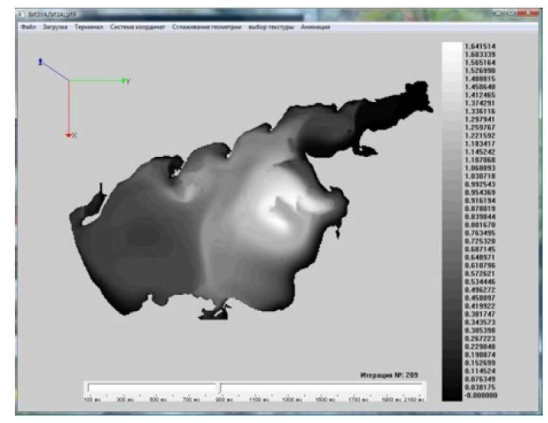

b)

Fig. 9. Results of "Azov3d" SC simulation: a) changes of biogenic pollutant concentration; b) changes of the Chlorella vulgaris Beijer green microalgae concentration

(28 days since the introduction of algae in water). The coefficients are as follows: $\mu=5 \cdot 10^{-10} ; D=0,001 ; S_{p}=1 ; f=3 ; \tau_{\varphi}=0,1 ; \varphi \in\{M, S, B\} ; \varepsilon=0,8 ; \alpha_{0}=0,1$;

$$
\gamma=0,0416
$$

As the verification criterion of developed models (1) - (4), (5), we consider the error estimation of simulation taking into account the available field data measurements. The error is calculated as follows:

$$
\delta=\sqrt{\sum_{k=1}^{n}\left(c_{k \text { nat }}-c_{k}\right)^{2}} / \sqrt{\sum_{k=1}^{n} c_{k n a t}^{2}},
$$

where $c_{k}$ nat is the value of harmful concentration obtained by field measurements [32]; $c_{k}$ is the value of harmful concentration calculated by the models (1) - (4), (5). The value of relative error $\delta$ was equaled to $12-24 \%$ at calculation of contaminant and microorganism concentrations.

\section{Conclusion}

We propose the complex of interrelated mathematical models of hydrodynamics and biological kinetics. The complex describes the oil products' transport in view of evaporation of light, neutral and no-evaporating pseudofractions of oil slick, dissolution and biodegradation $[30,32]$. The approximation of the convection-diffusion problem is performed on the basis of the space splliting schemes.

Research of the developed scheme shows that the scheme is stable at the Courant numbers in the interval $[0,0,75]$ and at the large Peclet numbers $(P e>20)$. The proposed scheme gives the numerical solution error, which is less than the solution error of the problem obtained by the discretization of standard difference schemes. On the basis of supercomputer, we develop the experimental software for mathematical modelling the possible scenarios of shallow waters' ecosystems on the example of the Azov Sea at oil spills. The decomposition methods of grid domains are used for computationally laborious convection-diffusion problems in parallel implementation taking into account the architecture of multiprocessor systems with distributed memory. Analysis of the CUDA architecture characteristics shows the applicability of algorithms for numerical implementation of the developed mathematical models of hydrophysics to construct the high-performance information systems.

Acknowledgements. This paper was partially supported by the grant no. 17-11-01286 of the Russian Science Foundation. 


\section{References}

1. Dembitsky S.I., Urtenov M.Kh., Sharpan M.V. Mathematical Modelling and Analysis of the Biological Destruction of Oil with Different Ways of Making Biological Products. Ecological Systems and Devices, 2007, no. 11, pp. 48-51.

2. Perevaryukha A.Yu. Uncertainty of Asymptotic Dynamics in Bioresource Management Simulation. Journal of Computer and Systems Sciences International, 2011, vol. 50, no. 3, pp. 491-498. DOI: 10.1134/S1064230711010151

3. Chetverushkin B.N. Resolution Limits of Continuous Media Models and Their Mathematical Formulations. Mathematical Models and Computer Simulations, 2013, vol. 5, no. 3, pp. 266279. DOI: $10.1134 / \mathrm{S} 2070048213030034$

4. Shiahn-wern Shyue, Hung-chun Sung, Yung-fang Chiu. Oil Spill Modeling Using 3D Cellular Automata for Coastal Waters. Proceeding of 17th International Offshore and Polar Engineering Conference, 2007, pp. 546-553.

5. Yihdego Y., Al-Weshah R.A. Hydrocarbon Assessment and Prediction Due to the Gulf War Oil Disaster, North Kuwait. Water Environment Research, 2017, vol. 89, no. 6, pp. 484-499. DOI: $10.2175 / 106143016 \mathrm{X} 14798353399250$

6. Chistyakov A.E., Nikitina A.V., Ougolnitsky G.A. et al. A Differential-Game Model of Prevention Zamora in Shallow Waters. Proceedings of the Conference Management of Large Systems, 2015, no. 55, pp. 343-361.

7. Johansen O. Dispersion of Oil from Drifting Slicks. Spill Technology Newsletter, 1982, pp. $134-149$.

8. Mackay D., Buist I., Mascarenhas R., Paterson S. Oil Spill Processes and Models. Ottawa, 1980.

9. Chistyakov A.E., Semenyakina A.A. The Application of Interpolation Methods for Reconstruction of the Bottom Surface. Izvestiya YuFU. Tekhnicheskie nauki, 2013, no. 4 (141), pp. 21-28.

10. Nikitina A.V., Sukhinov A.I., Ugolnitsky G.A. et al. Optimal Control of Sustainable Development in the Biological Rehabilitation of the Azov Sea. Mathematical Models and Computer Simulations, 2017, vol. 9, no. 1, pp. 101-107. DOI: 10.1134/S2070048217010112

11. Belotserkovskii O.M. Turbulentnost': novye podhody [Turbulence: New Approaches]. Moscow, Nauka, 2003.

12. Samarskii A.A. Teoriya raznostnyh shem [The theory of Difference Schemes]. Moscow, Nauka, 1977.

13. Belotserkovskii O.M., Gushhin V.A., Shhennikov V.V. Use of the Splitting Method to Solve Problems of the Dynamics of a Viscous Incompressible Fluid. Journal of Computational Mathematics and Mathematical Physics, 1975, vol. 15, no. 1, pp. 190-200. DOI: 10.1016/00415553(75) 90146-9

14. Abdusamadov A.S., Panarin A.P., Magomedov A.K. et al. The Solubility and Degradation of Oil in Seawater. South of Russia: Ecology, Development, 2012, vol. 1, pp. 165-166. DOI: $10.18470 / 1992-1098-2012-1-165-166$

15. Fay J.A. Physical Processes in the Spread of Oil on a Water Surface. Procceeding of Joint Conference on Prevention and Control of Oil Spills, 1971, pp. 463-467. DOI: 10.7901/21693358-1971-1-463

16. Akhmetov I.V., Gubaydullin I.M. Information-Analytical System of Chemical Technology Processes Modeling by the Use of Parallel Calculations. CEUR Workshop Proceedings of the 4th International Conference on Information Technology and Nanotechnology, Samara, 2018, pp. 139-145. DOI: 10.18287/1613-0073-2018-2212-139-145 
17. Copeland G., Wee Thiam-Yew. Current Data Assimilation Modelling for Oil Spill Contingency Planning. Environmental Modelling and Software, 2006, vol. 21, no. 2, pp. 142 155. DOI: $10.1016 /$ j.envsoft.2004.04.022

18. Tyutyunov Yu.V., Titova L.I., Senina I.N. Prey-Taxis Destabilizes Homogeneous Stationary State in Spatial Gause-Kolmogorov-Type Model for Predator-Prey System. Ecological Complexity, 2017, vol. 31, pp. 170-180. DOI: 10.1016/j.ecocom.2017.07.001

19. Unified State System of Information on the Situation in the World Ocean. Available at: esimo.ru/portal/auth/portal/arm-csmonitor/Settlement-Model + Complex (accessed 17 August 2018).

20. National Oceanic and Atmospheric Administration. Available at: hobitus.com/noaa (accessed 17 August 2018).

21. Analytical GIS. Available at: geo.iitp.ru/index.php (accessed 17 August 2018).

22. National Aeronautics and Space Administration. Available at: nasa.gov (accessed 17 August 2018).

23. SRC "Planet". Available at: planet.iitp.ru/index1.html (accessed 17 August 2018).

24. Resolution of the Government of the Russian Federation on April 15, 2002. No. 240 "On the Procedure for Organizing the Activities for Prevention and Liquidation of Oil Spills in the Russian Federation".

25. Nikitina A.V., Semenov I.S. Parallel Implementation of the Toxic Algae Dynamics Model in the Azov Sea Using the Multithreading in the Windows Operating System. Izvestiya YuFU. Tekhnicheskie nauki, 2013, no. 1 (138), pp. 130-135.

26. Tkalich P., Chan E.S. Vertical Mixing of Oil Droplets by Breaking Waves. Marine Pollution Bulletin, 2002, vol. 44, no. 11, pp. 152-161. DOI: 10.1016/S0025-326X(02)00178-9

27. Chistyakov A.E., Khachunts D.S. Software Implementation of the Two-Dimensional Problem of Air Environment Motion. Izvestiya YuFU. Tekhnicheskie nauki, 2013, no. 4 (141), pp. 15-21.

28. Modelling of Emergency Oil Spills and Oil Products for Planning Actions in Emergency Conditions. Moscow, ArcReview, DATA+, 2003.

29. Sukhinov A.I., Chistyakov A.E. Adaptive Modified Alternating Triangular Iterative Method for Solving Grid Equations with a Non-Self-Adjoint Operator. Mathematical Models and Computer Simulations, 2012, vol. 4, no. 4, pp. 398-409. DOI: 10.1134/S2070048212040084

30. Gushchin V.A., Sukhinov A.I., Nikitina A.V. et al. A Model of Transport and Transformation of Biogenic Elements in the Coastal System and Its Numerical Implementation. Computational Mathematics and Mathematical Physics, 2018, vol. 58, no. 8, pp. 1316-1333. DOI: $10.1134 /$ S0965542518080092

31. Yakushev E.V., Sukhinov A.I., Lukashev Yu.F. et al. Comprehensive Oceanological Studies of the Sea of Azov During Cruise 28 of R/V Akvanavt (July-August 2001). Oceanology, 2003, vol. 43 , no. 1 , pp. 39-47.

32. Sukhinov A.I., Nikitina A.V., Semenyakina A.A., Chistyakov A.E. Complex of Models, Explicit Regularized Schemes of High-Order of Accuracy and Applications for Predictive Modeling of After-Math of Emergency Oil Spill. Proceedings of the 10th Annual International Scientific Conference on Parallel Computing Technologies, 2016, vol. 1576, pp. 308-319.

Received April 8, 2019 


\title{
СУПЕРКОМПЬЮТЕРНОЕ МОДЕЛИРОВАНИЕ НЕФТЯНЫХ РАЗЛИВОВ В АЗОВСКОМ МОРЕ
}

\author{
А.И. Сухинов ${ }^{1}$, А.Е. Чистяков ${ }^{1}$, А.А. Филина ${ }^{2}$, А.В. Никитина ${ }^{3}$, \\ В.Н. Литвинов ${ }^{4}$ \\ 1 Донской государственный технический университет, г. Ростов-на-Дону, Российская \\ Федерация \\ ${ }^{2} \mathrm{OOO} \ll$ «ИЦ супер-ЭВМ и нейрокомпьютеров», г. Таганрог, Российская Федерация \\ 3 Южный федеральный университет, г. Таганрог, Российская Федерация \\ ${ }^{4}$ Азово-Черноморский инженерный институт ФГБОУ ВО Донской ГАУ, г. Зерноград, \\ Российская Федерация
}

Исследование микробиологической деструкции нефтяных загрязнений в мелководном водоеме с учетом фракционного состава нефти, а также гидродинамических и химико-биологических свойств воды проводилось на многопроцессорной вычислительной системе с распределенной памятью. Предложен комплекс взаимосвязанных прецизионных моделей для моделирования динамики микробиологической деградации углеводородов в Азовском море. Для дискретизации моделей использовались схемы расщепления по пространству с учетом частичной заполненности ячеек расчетной области, благодаря чему точность вычислений была значительно повышена, а время выполнения расчетов сократилось. На супер-ЭВМ разработано экспериментальное программное обеспечение, предназначенное для прогнозного моделирования экологической ситуации в мелководном водоеме при нефтяном и других загрязнениях при природных и индустриальных вызовах.

Ключевые слова: небтяное загрязнение; биодеградация небтяных углеводородов; мелководный водоем; математическая модель; алгоритм; супер-ЭВМ.

\section{Литература}

1. Дембицкий, С.И. Математическое моделирование и анализ биологической деструкции нефти при разных способах внесения биопрепаратов / С.И. Дембицкий, М.Х. Уртенов, М.В. Шарпан // Экологические системы и приборы. - 2007. - № 11. - С. 48-51.

2. Perevaryukha, A.Yu. Uncertainty of Asymptotic Dynamics in Bioresource Management Simulation / A.Yu. Perevaryukha // Journal of Computer and Systems Sciences International. - 2011. - V. 50, № 3. - P. 491-498.

3. Chetverushkin, B.N. Resolution Limits of Continuous Media Models and Their Mathematical Formulations / B.N. Chetverushkin // Mathematical Models and Computer Simulations. 2013. - V. 5, № 3. - P. 266-279.

4. Shiahn-wern Shyue. Oil Spill Modeling Using 3D Cellular Automata for Coastal Waters / Shiahn-wern Shyue, Hung-chun Sung, Yung-fang Chiu // Procceding of 17th International Offshore and Polar Engineering Conference. - 2007. - P. 546-553.

5. Yihdego, Y. Hydrocarbon Assessment and Prediction Due to the Gulf War Oil Disaster, North Kuwait / Y. Yihdego, R.A. Al-Weshah // Water Environment Research. - 2017. V. 89, № 6. - P. 484-499.

6. Чистяков, А.Е. Дифференциально-игровая модель предотвращения заморов в мелководных водоемах / А.Е. Чистяков, А.В. Никитина, Г.А. Угольницкий и др. // Управление большими системами. - 2015. - № 55. - С. 343-361.

Вестник ЮУрГУ. Серия «Математическое моделирование

и программирование» (Вестник ЮУрГУ ММП). 2019. Т. 12, № 3. С. 115-129 
7. Johansen, O. Dispersion of Oil from Drifting Slicks / O. Johansen // Spill Technology Newsletter. - 1982. - P. 134-149.

8. Mackay, D. Oil Spill Processes and Models / D. Mackay, I. Buist, R. Mascarenhas, S. Paterson. - Ottawa, 1980.

9. Чистяков, А.Е. Применение методов интерполяции для восстановления донной поверхности / А.Е. Чистяков, А.А. Семенякина // Известия ЮФУ. Технические науки. -2013. № 4 (141). - C. 21-28.

10. Nikitina, A.V. Optimal Control of Sustainable Development in the Biological Rehabilitation of the Azov Sea / A.V. Nikitina, A.I. Sukhinov, G.A. Ugolnitsky et al. // Mathematical Models and Computer Simulations. - 2017. - V. 9, № 1. - P. 101-107.

11. Белоцерковский, О.М. Турбулентность: новые подходы / О.М. Белоцерковский. - М.: Наука, 2003.

12. Самарский, А.А. Теория разностных схем / А.А. Самарский. - М.: Наука, 1977.

13. Белоцерковский, О.М. Метод расщепления в применении к решению задач динамики вязкой несжимаемой жидкости / О.М. Белоцерковский, В.А. Гущин, В.В. Щенников // Журнал вычислительной математики и математической физики. -1975 . - Т. 15, № 1. C. $190-200$.

14. Абдусамадов, А.С. Растворимость и деструкция нефти в морской воде / А.С. Абдусамадов, А.П. Панарин, А.К. Магомедов и др. // Юг России: экология, развитие. - 2012. T. 7, № 1. - C. 165-166.

15. Fay, J.A. Physical Processes in the Spread of Oil on a Water Surface / J.A. Fay // Proceeding of Joint Conference on Prevention and Control of Oil Spills. - 1971. - P. 463-467.

16. Akhmetov, I.V. Information-Analytical System of Chemical Technology Processes Modeling by the Use of Parallel Calculations / I.V. Akhmetov, I.M. Gubaydullin // CEUR Workshop Proceedings of the 4th International Conference on Information Technology and Nanotechnology. - 2018. - P. 139-145.

17. Copeland, G. Current Data Assimilation Modelling for Oil Spill Contingency Planning / G. Copeland, Wee Thiam-Yew // Environmental Modelling and Software. - 2006. - V. 21, № 2. - P. $142-155$.

18. Tyutyunov, Yu.V. Prey-Taxis Destabilizes Homogeneous Stationary State in Spatial GauseKolmogorov-Type Model for Predator-Prey System / Yu.V. Tyutyunov, L.I. Titova, I.N. Senina // Ecological Complexity. - 2017. - V. 31. - P. 170-180.

19. Портал «Единая государственная система информации об обстановке в Мировом океане». - URL: esimo.ru/portal/auth/portal/arm-csmonitor/Settlement-Model+Complex (дата обращения: 17.08.2018).

20. National Oceanic and Atmospheric Administration. - URL: hobitus.com/noaa (дата обращения: 17.08.2018).

21. «Аналитические ГИС».- URL: geo.iitp.ru/index.php (дата обращения: 17.08.2018).

22. National Aeronautics and Space Administration (NASA). - URL: nasa.gov (дата обращения: 17.08.2018).

23. ФГБУ «Научно-исследовательский центр космической гидрометеорологии «Планета». - URL: planet.iitp.ru/index1.html (дата обращения: 17.08.2018).

24. Постановление Правительства РФ № 240 от 15.03.2002 « порядке организации мероприятий по предупреждению и ликвидации разливов нефти и нефтепродуктов на территории Российской Федерации». 
25. Никитина, А.В. Параллельная реализация модели динамики токсичной водоросли в Азовском море с применением многопоточности в операционной системе Windows / А.В. Никитина, И.С. Семенов // Известия ЮФУ. Технические науки. - 2013. № 1 (138). - C. 130-135.

26. Tkalich, P. Vertical Mixing of Oil Droplets by Breaking Waves / P. Tkalich, E.S. Chan // Marine Pollution Bulletin. - 2002. - V. 44, № 11. - P. 152-161.

27. Чистяков, А.Е. Программная реализация двумерной задачи движения воздушной среды / А.Е. Чистяков, Д.С. Хачунц // Известия ЮФУ. Технические науки. - 2013. № 4 (141). - С. 15-21.

28. Моделирование аварийных разливов нефти и нефтепродуктов для планирования действий в чрезвычайных ситуациях. - M.: ArcReview, DATA+, 2003.

29. Sukhinov, A.I. Adaptive Modified Alternating Triangular Iterative Method for Solving Grid Equations with a Non-Self-Adjoint Operator / A.I. Sukhinov, A.E. Chistyakov // Mathematical Models and Computer Simulations. - 2012. - V. 4, № 4. - P. 398-409.

30. Gushchin, V.A. A Model of Transport and Transformation of Biogenic Elements in the Coastal System and Its Numerical Implementation / V.A. Gushchin, A.I. Sukhinov, A.V. Nikitina et al. // Computational Mathematics and Mathematical Physics. - 2018. V. 58, № 8. - P. 1316-1333.

31. Yakushev, E.V. Comprehensive Oceanological Studies of the Sea of Azov During Cruise 28 of R/V Akvanavt (July-August 2001) / E.V. Yakushev, A.I. Sukhinov, Yu.F. Lukashev et al. // Oceanology. - 2003. - V. 43, № 1. - P. 39-47.

32. Сухинов, А.И. Комплекс моделей, явных регуляризованных схем повышенного порядка точности и программ для предсказательного моделирования последствий аварийного разлива нефтепродуктов / А.И. Сухинов, А.В. Никитина, А.А. Семенякина, А.Е. Чистяков // Параллельные вычислительные технологии. - 2016. - Т. 1576. - С. 308-319.

Александр Иванович Сухинов, доктор физико-математических наук, профессор, кафедра «Математика и информатика», НИИ Математического моделирования и прогнозирования сложных систем, Донской государственный технический университет (г. Ростов-на-Дону, Российская Федерация), sukhinov@gmail.com.

Александр Евгеньевич Чистяков, доктор физико-математических наук, професcop, кафедра «Программное обеспечение вычислительной техники и автоматизированных систем», Донской государственный технический университет (г. Ростов-наДону, Российская Федерация), cheese_05@mail.ru.

Алена Александровна Филина, кандидат технических наук, ООО «НИЦ суперЭВМ и нейрокомпьютеров» (г. Таганрог, Российская Федерация), j.a.s.s.y@mail.ru.

Алла Валерьевна Никитина, доктор технических наук, профессор, кафедра «Интеллектуальные и многопроцессорные системы», Южный федеральный университет (г. Таганрог, Российская Федерация), nikitina.vm@gmail.com.

Владимир Николаевич Литвинов, кафедра «Теплоэнергетика и информационноуправляющие системы», Азово-Черноморский инженерный институт ФГБОУ ВО Донской ГАУ (г. Зерноград, Российская Федерация), litvinovvn@rambler.ru.

Поступила в редакцию 8 апреля 2019 г.

Вестник ЮУрГУ. Серия «Математическое моделирование

и программирование» (Вестник ЮУрГУ ММП). 2019. Т. 12, № 3. С. 115-129 